\title{
ע Rekisteritutkimus psyykenlääkkeiden käytön yleisyydestä oululaisilla omaishoitajilla vuonna 2013
}

Omaishoitajan psyykkisen terveydentilan ja kuormittuneisuuden indikaattorina voidaan pitää hänen psyykenlääkkeiden käyttöään. Aiheesta ei ole julkaistu suomalaista tutkimustietoa. Tavoitteenamme oli selvittää, erosivatko psyykenlääkkeitä kalenterivuoden aikana ostaneiden osuudet omaishoitajien ja muun saman ikäisen väestön välillä. Lisäksi kuvailemme omaishoidettavien terveydentilaa ja psyykenlääkkeen oston yleisyyttä. Rekisteritutkimuksemme kohteena olivat Oulussa vuonna 2013 asuneet henkilöt, joiden tietoja analysoitiin kuvailevin tilastollisin menetelmin ja logistisella regressioanalyysilla.

Omaishoitajien $(\mathrm{N}=1905)$ keski-ikä oli 59 vuotta ja $62 \%$ oli naisia. Keskimäärin yksi neljästä omaishoitajasta oli ostanut jotain psyykenlääkettä sairausvakuutuksen korvaamana. Työikäiset (18-64-vuotiaat) omaishoitajat ostivat yleisimmin masennuslääkettä (16\%) ja ikääntyneet (65-95-vuotiaat) unilääkettä (18\%). Psyykenlääkettä ostaneita oli enemmän työikäisissä omaishoitajissa kuin vertailuväestössä (23\% vs. $14 \%$ ); ikääntyneillä ei ollut merkitsevää eroa. Kun psyykenlääkkeen ostoa tarkasteltiin tarkemmin neljässä yleisimmässä lääkeryhmässä, havaittiin vertailussa sukupuolittaisia eroja: työikäisen miespuolisen omaishoitajan unilääkkeen ostamisen vetosuhde (odds ratio) väestöön verrattuna oli I,4 ja naisilla masennuslääkkeen ostamisen vetosuhde I,2. Psykoosiläkkeen käyttö oli naispuolisilla omaishoitajilla vertailuväestöä harvinaisempaa: työikäisellä naisella vetosuhde oli 0,8 ja ikääntyneellä 0,6. Omaishoidettavien keski-ikä oli 60 vuotta, ja ikääntyneitä kuoli 13\% vuoden 2013 aikana. Lähes joka toisella työikäisellä ja ikääntyneellä omaishoidettavalla oli vähintään yksi psyykenlääkkeen osto.

Omaishoito jatkuu usein vuosia, joten omaishoitajien kanssa toimivien tulee kiinnittää huomiota hoitajan psyykkiseen jaksamiseen. Omaishoitoa tukevia palveluja ja järjestelyjä tulee kehittää entisestään tukemalla myös omaishoitajan psyykettä.

ASIASANAT: avohoito, masennus, omaishoidettava, omaishoito, unilääkkeet LAURI VIRTA, PÄIVI TILLMAN, JENNI BLOMGREN

\section{YDINASIAT}

- Suomalaisten omaishoitajien psyykenlääkkeiden käytöstä ei ole aiempaa tutkimustietoa.

- Vuoden 2013 aikana psyykenlääkettä osti yksi neljästä oululaisesta omaishoitajasta.

- Työikäisissä omaishoitajissa oli enemmän psyykenlääkettä ostaneita kuin vertailuväestössä, ikääntyneillä ei ollut merkitsevää eroa.
- Omaishoitosuhteelle on merkityksellistä omaishoitajan psyykkinen jaksaminen, johon omaishoitajien kanssa toimivien tulee kiinnittää huomiota. 


\section{JOHDANTO}

Omaishoitoon on panostettu Suomessa viime aikoina niin kehittämisohjelmalla (1) kuin pääministeri Juha Sipilän hallituskaudelleen asettamalla kärkihankkeella (2). Omaishoidosta halutaan keskeinen keino ikääntyneen kotona asumisen tukemiseen, kun vanhuspoliittisena tavoitteena on kotona asuminen mahdollisimman pitkään lisäämällä avohoitoa ja vähentämällä laitoshoitoa (3). Omaishoito mahdollistaa kotona asumisen myös toimintakyvyltään heikentyneelle lapselle tai työikäiselle, joka tarvitsee jatkuvaa hoivaa (1).

Omaishoidon ehdoista säädetään laissa omaishoidon tuesta (4). Siinä omaishoito määritellään vanhuksen, vammaisen tai sairaan henkilön hoidon ja huolenpidon järjestämiseksi kotioloissa omaisen tai muun hoidettavalle läheisen henkilön toimesta. Laissa omaishoitajalla tarkoitetaan henkilöä, joka on tehnyt sopimuksen omaishoidosta hoidettavan kotikunnan kanssa. Omaishoidon tuki koostuu hoidettavalle järjestettävistä palveluista, hoitajalle maksettavasta hoitopalkkiosta ja hänelle järjestettävistä vapaista sekä omaishoitoa tukevista palveluista. Myös arkikielessä käytetään yleisesti omaishoidon käsitettä epävirallisesti, kun omainen huolehtii läheisestään, joka ei omatoimisesti selviydy arjestaan ja on hoivan tarpeessa - ilman että kunta maksaisi hoitajalle palkkiota.

Vuonna 2013 noin 43000 omaishoitajalla (1 \% 18 ikävuotta täyttäneestä väestöstä) oli kunnan kanssa tehty sopimus läheisensä omaishoidosta (5). Heistä arviolta 58 prosenttia hoiti omaa puolisoaan tai kumppaniaan, 25 prosenttia lastaan, 12 prosenttia vanhempaansa ja loput muuta omaistaan tai läheistään (6). Uusimman, vuoden 2017 tilastotiedon mukaan noin 46000 henkilöllä oli virallinen omaishoitosopimus, joten viidessä vuodessa virallisten omaishoitajien määrä suureni lähes 15 prosenttia. Epävirallisena omaishoitajana läheisensä kotona selviytymistä auttaa säännöllisesti suuri määrä, arviolta yksi viidestä 30 vuotta täyttäneestä suomalaisesta (7).

Eräissä Euroopan maissa, kuten Saksassa, Italiassa ja Baltian maissa, on lakisääteinen velvoite vastata puolison elatuksen lisäksi myös hänen muusta huolenpidostaan (1). Vastaavasti näissä maissa aikuisten lasten velvollisuus on huolehtia omista vanhemmistaan. Omaishoitajille maksetaan julkisesti rahoitettua omaishoidon tukea Suomen lisäksi ainakin Ruotsissa, Iso-
Britanniassa ja Irlannissa (1). Omaishoitajan käsite sekä omaishoidon mahdollisen tuen maksamisen ja käytön lainsäädännölliset puitteet eroavat maittain, joten Suomen virallisia omaishoitajia ja muiden maiden omaishoitajia koskevien tutkimusten tuloksia tulee vertailla varauksin toisiinsa.

Omaishoito edellyttää omaishoitajalta riittävää fyysistä ja psyykkistä terveyttä ja kuntoa. $\mathrm{Ne}$ toimivat myös omaishoidon tuen myöntämisen edellytyksinä: omaishoitolain $3 \mathbb{S}: \mathrm{n}$ mukaan hoitajan terveyden ja toimintakyvyn on vastattava omaishoidon asettamia vaatimuksia (4). Omaishoidolla saattaa olla myönteisten vaikutusten ohella myös kielteisiä vaikutuksia niin omaishoitajan kuin omaishoidettavan hyvinvointiin ja terveydentilaan (8-11).

Masennus, unen ongelmat ja stressi ovat systemaattisten katsausten mukaan omaishoitajilla yleisempiä kuin heidän verrokeillaan tutkimuksissa, joista pääosa on kohdistunut ikääntyneiden dementiapotilaiden hoitajiin $(12,13)$. Kyseiset yhteydet voivat osittain selittyä myös valikoitumisella: jotkut henkilöt ovat saattaneet hakeutua omaishoitajaksi tietyn tyyppisin personallisuuspiirtein, jotka altistavat heitä esimerkiksi masennukselle. Siksi ei tule tutkia yksinomaan hoitoprosessin tai omaishoidettavien ominaisuuksien yhteyksiä hoitajien psyykkiseen oireiluun tai psyykenlääkkeiden käyttöön, vaan tärkeää on myös huomioida omaishoitajien taustaominaisuuksia (14).

Masennuslääkettä käytti vuonna 1998 yksi viidestä amerikkalaisten dementiapotilaiden depressiivisesti oireilleesta omaishoitajasta (15). Omaishoitajien psyykenlääkkeiden käytön yleisyyden ja määrän on tulkittu kuvastavan epäsuorasti omaishoitoon mahdollisesti liittyvää psyykkistä kuormittuneisuutta (16). Dementiapotilaiden omaishoitajien ja ikääntyneiden omaishoitajien psyykenlääkkeiden käyttö on havaittu verrokkeja yleisemmäksi amerikkalaisissa tutkimuksissa (1618). Omaishoidon intensiivisyyden ja sitovuuden, lähinnä ajallisen keston (viikkotuntien määrän) lisäyksellä on havaittu heikko positiivinen yhteys omaishoitajien psyykenläkityksen käytön todennäköisyyteen, mikä osaltaan tukee hypoteesia omaishoidon kausaalisista vaikutuksista hoitajan psyykkiseen terveydentilaan $(19,20)$.

Koska suomalaisten omaishoitajien psyykenlääkkeiden käytön yleisyydestä ei ollut tietoa, 
päädyimme tutkimaan aihetta Kelan sairausvakuutuksen lääkekorvaustietojen avulla. Lähtöoletuksemme oli, että omaishoitajan psyykenlääkkeiden käyttöä voitaisiin pitää hänen psyykkisen terveydentilansa ja kuormittuneisuutensa korvikemittarina. Tutkimuskysymykseksi muodostui, erosivatko mitä tahansa psyykenlääkettä ostaneiden ja eri psyykenlääkeryhmiä ostaneiden osuudet omaishoitajien ja saman ikäisen vertailuväestön välillä. Syventääksemme kuvaa omaishoidon kuormittavuudesta hoitajille kuvailemme lisäksi omaishoidettavien sairastavuutta hyödyntämällä tietoja $\mathrm{mm}$. heidän ostamistaan psyykenlääkkeistä ja Kelan heille maksamista vammaisetuuksista.

\section{AINEISTO JA MENETELMÄT}

Kyseessä on takautuva rekisteritutkimus poikkileikkausasetelmalla. Perusjoukon muodostivat Oulussa vuoden 2013 aikana asuneet henkilöt. Aineistokokonaisuus asukkaiden sote-palveluiden ja etuuksien käytöstä vuoden aikana on alkujaan muodostettu Oulun kaupungin, Kelan, Nordic Healthcare Groupin, Sitran ja Oulussa toimivien työterveyshuollon palveluntuottajien yhteistyönä (21).

Omaishoidon hoitopalkkio on veronalaista tuloa, ja verotustietojen perusteella omaishoitajiksi identifioitiin ne oululaiset, joille vuonna 2013 maksettiin omaishoitajan tai perhehoitajan palkkiota muttei perhehoitajan kulukorvausta. Tutkimusjoukosta jätettiin pois vuoden 2013 aikana kuolleet, koska halusimme selvittää omaishoitajien lääkeostoja koko kalenterivuoden ajalta. Omaishoitajien määräksi tuli 1905 henkilöä, jotka olivat iältään 18-95-vuotiaita. Muu saman ikäinen, vuoden 2013 lopun oululainen väestö toimi vertailuryhmänä, lukuun ottamatta omaishoidettavia. Kaikki vuoden 2013 kuluessa omaishoidossa olleet, yhteensä 1942 henkilöä (mukana myös ko. vuoden aikana kuolleet) identifioitiin Oulun kaupungin sosiaalipalvelujen tiedoista. Henkilötasolla omaishoitajaa ja hänen hoidettavaansa ei ollut mahdollista yhdistää toisiinsa, joten osa-aineistoja tarkasteltiin erillisinä ryhminä.

Aineisto sisältää Kelan rekisteritiedot tutkittavien niistä vuoden 2013 lääkeostoista, joista oli maksettu sairausvakuutuksen korvaus. Psyykenlääkkeiden ostot ryhmiteltiin WHO:n ATC(anatomis-terapeuttis-kemiallinen) luokituksen koodeihin perustuviin lääkeryhmiin: psykoosilääkkeet (N05A), neuroosilääkkeet ja rauhoittavat aineet (N05B), unilääkkeet (N05C), masennuslääkkeet (N06A), mielialaa tasaavat lääkkeet, keskushermostoa stimuloivat lääkeaineet (N06B) ja psyykenlääkkeiden yhdistelmävalmisteet (N06C) (22). Lisäksi ikääntyneillä tarkasteltiin myös dementialääkkeen (N06D) ostamista. Tulosmuuttujana esitetään psyykenlääkettä vuoden 2013 aikana ostaneiden osuuksia sekä lääkeryhmittäin että kaikkiaan. Omaishoitajien psyykenlääkkeen kulutuksen määrää arvioitiin kalenterivuoden ostokertojen lukumäärillä: 1 tai 2 ostoa vuodessa tulkittiin satunnaiseksi käytöksi ja sitä useampi vuosiosto säännölliseksi, päivittäiseksi tai vastaavaksi käytöksi.

Tutkittavia kuvaavina taustatietoina käytettiin ikää, sukupuolta, verotukseen perustuvaa tietoa ansiotyöstä (omaishoitajilla) sekä heidän sairastavuuttaan käyttäen Kelan tietoja vammaisetuuksien ja lääkkeiden erityiskorvausoikeuksien saannista ja niiden perusteena olleista diagnooseista. Kelan vammaisetuuksien (alle 16-vuotiaan vammaistuen, 16 vuotta täyttäneen vammaistuen ja eläkettä saavan hoitotuen) tarkoituksena on tukea vammaisen tai pitkäaikaisesti sairaan henkilön selviytymistä jokapäiväisessä elämässä sekä hänen toimintakykynsä ylläpitämistä, hänen kotona asumistaan, kuntoutustaan ja hoitoaan (23). Siten vammaisetuuksilla on yhteisiä piirteitä omaishoidon kanssa, joskin Kela maksaa vammaisetuutta vain apua tarvitsevalle, ei hänen hoitajalleen.

Omaishoitajien taustatietoja ja psyykenlääkettä käyttäneiden osuuksia tarkasteltiin suhteessa vertailuväestöön ristiintaulukoimalla sekä muuttujien välisten yhteyksien tilastollista merkitsevyyttä khiin neliö -testillä. Neljää yleisintä psyykenlääkeryhmää ostaneiden omaishoitajien osuuksille muuhun väestöön verrattuna laskettiin vetosuhteet (odds ratio) ja niiden $95 \%$ :n luottamusvälit (lv) ordinaalisella logistisella regressioanalyysillä, jossa vastemuuttujana käytettiin psyykenlääkeryhmän ostojen määrää kolmiluokkaisena: ei yhtään ostoa, 1-2 ostoa ja enemmän kuin 2 ostoa vuoden aikana (24). Omaishoidon lisäksi käytimme mallin selittävinä muuttujina ansiotyötä ja lääkkeiden erityiskorvausoikeutta (kummatkin kaksiluokkaisina), jotka alustavissa analyyseissä olivat merkitsevästi yhteydessä psyykenlääkkeiden ostamiseen. 
Taulukko 1. Oululaisten omaishoitajien ${ }^{1}$ ja heidän vertailuväestönsä taustatietoja ikäryhmittäin vuonna 2013.

\begin{tabular}{|c|c|c|c|c|c|c|}
\hline & \multicolumn{3}{|c|}{ 18-64-vuotiaat } & \multicolumn{3}{|c|}{ 65-95-vuotiaat } \\
\hline & $\begin{array}{l}\text { Omais- } \\
\text { hoitajat } \\
N=1110\end{array}$ & $\begin{array}{c}\text { Muu } \\
\text { väestö } \\
\mathrm{N}=127374\end{array}$ & p-arvo & $\begin{array}{c}\text { Omais- } \\
\text { hoitajat } \\
\mathrm{N}=795\end{array}$ & $\begin{array}{c}\text { Muu } \\
\text { väestö } \\
\mathrm{N}=24552\end{array}$ & p-arvo \\
\hline Osuus omaishoitajista, \% & 58,3 & & & 41,7 & & \\
\hline Omaishoitajien väestöosuus, \% & 0,9 & & & 3,0 & & \\
\hline Naisia, \% & 71,7 & 49,2 & $<0,001$ & 63,4 & 57,9 & 0,002 \\
\hline Keski-ikä, vuosia (keskihajonta) & $46,4(12,1)$ & $38,6(13,5)$ & $<0,001$ & $75,4(6,7)$ & $73,8(7,1)$ & $<0,001$ \\
\hline Pääasiallisena tulolähteenä ansiotyö, \% & 52,3 & 72,3 & $<0,001$ & - & - & \\
\hline Kelan vammaisetuus, \% & 4,7 & 2,5 & $<0,001$ & 10,1 & 16,9 & $<0,001$ \\
\hline $\begin{array}{l}\text { Vähintään } 1 \text { korvattu lääkeosto } \\
\text { vuodessa, \% }\end{array}$ & 79,9 & 68,2 & $<0,001$ & 94,2 & 91,4 & 0,005 \\
\hline Lääkitykseen erityiskorvausoikeus, \% & 30,6 & 19,8 & $<0,001$ & 71,8 & 68,1 & 0,025 \\
\hline
\end{tabular}

${ }^{1}$ Omaishoidon tukea vuoden 2013 aikana saaneet

Koska kolmessa keskeisessä lääkeryhmässä (psykoosilääkkeet, unilääkkeet sekä neuroosilääkkeet ja rauhoittavat aineet) havaittiin tilastollisesti merkitsevä interaktio sukupuolen ja iän välillä, päätettiin kaikkien neljän keskeisen lääkeryhmän kohdalla estimoida omaishoitajille erilliset mallit 18-64-vuotiaille ja 65-95-vuotiaille sukupuolittain. Omaishoidettavien tietoja tarkasteltiin taulukoimalla kolmessa ikäryhmässä (1-15-vuotiaat, 16-64-vuotiaat ja 65-101-vuotiaat) ja ikäryhmien välisten erojen merkitsevyyksiä laskettiin khiin neliö -testin avulla. Aineisto analysoitiin SAS 9.4-tilasto-ohjelmalla.

\section{EETTINEN ARVIO}

Tutkimusaineistoon on käyttöluvat Oulun kaupungilta, THL:stä, Kelasta ja Tilastokeskuksesta. Tutkittaviin ei oltu yhteydessä. Aineiston keruu ei edellyttänyt eettistä ennakkoarviota, koska kyseessä on rekisteritutkimus.

\section{TULOKSET}

\section{OMAISHOITAJAT}

Naisten osuus omaishoitajista oli vertailuväestöä suurempi (68\% vs. $51 \%$ ) ja omaishoitajat olivat vanhempia (keski-ikä 59 vuotta) kuin vertailuväestö (keski-ikä 44 vuotta). Omaishoitajien ja vertailuväestön taustatietoja eriteltynä työikäisiin ja ikääntyneisiin esitetään taulukossa 1. Vuoden 2013 lopun Oulussa omaishoitajien väestöosuus oli $1,2 \%$ : työikäisten $0,9 \%$ ja ikääntyneiden $3,0 \%$.

Sairausvakuutuksen korvaamia lääkeostoja vuoden 2013 aikana oli useammalla omaishoitajalla kuin vertailuväestöön kuuluvalla (taulukko 1). Lääkehoitojen erityskorvausoikeuksia koskevien tietojen perusteella myös vaikeat pitkäaikaissairaudet olivat yleisempiä omaishoitajilla kuin vertailuväestöllä. Työikäisillä omaishoitajilla ansiotyö tutkimusvuoden pääasiallisena tulolähteenä oli harvinaisempaa (52\%) kuin vertailuväestöllä $(72 \%$; p<0,001). Kelan vammaisetuuksien saaminen oli työikäisillä omaishoitajilla yleisempää kuin vertailuväestössä, mutta ikääntyneillä suhde oli päinvastainen (taulukko 1).

Jotain psyykenlääkettä vuoden aikana osti useampi työikäinen omaishoitaja (23\%) kuin heidän vertailuväestönsä tutkittava (14\%; $\mathrm{p}<0,001$ ) (Taulukko 2). Työikäiset omaishoitajat ostivat vertailuväestöä yleisemmin kolmen psyykenlääkeryhmän lääkkeitä: masennuslääkettä (16\% vs. $9 \%$; p<0,001) unilääkettä (9\% vs. $5 \%$; $<0,001)$ sekä neuroosilääkettä ja rauhoittavaa ainetta ( $5 \%$ vs. $2 \%$; p<0,001). Vieläkin selkeämmin omaishoitajien ja vertailuväestön väliset erot tulivat esiin tarkasteltaessa em. lääkkeiden säännöllistä käyttöä (yli kahta ostoa vuodessa; taulukko 2). Psyykenlääkettä osti 
Taulukko 2. Vuoden 2013 aikana eri psyykenlääkeryhmien lääkkeitä ostaneiden vakioimattomat osuudet (\%) oululaisilla omaishoitajilla ja heidän vertailuväestöllään ikäryhmittäin.

\begin{tabular}{|c|c|c|c|c|c|c|c|c|}
\hline \multirow[b]{2}{*}{ Lääkeryhmä } & \multirow[b]{2}{*}{$\begin{array}{l}\text { ATC- } \\
\text { koodi }\end{array}$} & \multirow[b]{2}{*}{$\begin{array}{c}\text { Ostojen } \\
\mathrm{lkm} / \\
\text { vuosi }\end{array}$} & \multicolumn{3}{|c|}{ 18-64-vuotiaat } & \multicolumn{3}{|c|}{ 65-95-vuotiaat } \\
\hline & & & $\begin{array}{c}\text { Omais- } \\
\text { hoitajat } \\
\mathrm{N}=1110 \\
\%\end{array}$ & $\begin{array}{c}\text { Muu } \\
\text { väestö } \\
\mathrm{N}=127374 \\
\%\end{array}$ & $\mathrm{p}$-arvo & $\begin{array}{c}\text { Omais- } \\
\text { hoitajat } \\
\mathrm{N}=795 \\
\%\end{array}$ & $\begin{array}{c}\text { Muu } \\
\text { väestö } \\
\mathrm{N}=24552 \\
\%\end{array}$ & p-arvo \\
\hline $\begin{array}{l}\text { Psykoosiläk̈keet } \\
\text { (pois lukien litium) }\end{array}$ & N05A & $\begin{array}{c}1-2 \\
>2 \\
\text { kaikki }\end{array}$ & $\begin{array}{l}1,3 \\
2,7 \\
4,0\end{array}$ & $\begin{array}{l}1,0 \\
2,3 \\
3,3\end{array}$ & 0,434 & $\begin{array}{l}1,0 \\
1,3 \\
2,3\end{array}$ & $\begin{array}{l}1,3 \\
3,4 \\
4,6\end{array}$ & 0,004 \\
\hline $\begin{array}{l}\text { Neuroosilääkkeet ja } \\
\text { rauhoittavat aineet }\end{array}$ & N05B & $\begin{array}{c}1-2 \\
>2 \\
\text { kaikki }\end{array}$ & $\begin{array}{l}2,0 \\
2,7 \\
4,7\end{array}$ & $\begin{array}{l}1,2 \\
1,2 \\
2,4\end{array}$ & $<0,001$ & $\begin{array}{l}2,8 \\
1,8 \\
4,5\end{array}$ & $\begin{array}{l}2,4 \\
2,5 \\
4,9\end{array}$ & 0,343 \\
\hline Unilääkkeet & N05C & $\begin{array}{c}1-2 \\
>2 \\
\text { kaikki }\end{array}$ & $\begin{array}{l}4,6 \\
3,9 \\
8,5\end{array}$ & $\begin{array}{l}2,9 \\
1,6 \\
4,5\end{array}$ & $<0,001$ & $\begin{array}{c}9,1 \\
9,2 \\
18,2\end{array}$ & $\begin{array}{c}8,0 \\
7,7 \\
15,7\end{array}$ & 0,152 \\
\hline Masennuslääkkeet & N06A & $\begin{array}{c}1-2 \\
>2 \\
\text { kaikki }\end{array}$ & $\begin{array}{c}4,6 \\
10,9 \\
15,5\end{array}$ & $\begin{array}{l}3,5 \\
5,3 \\
8,8\end{array}$ & $<0,001$ & $\begin{array}{c}3,5 \\
6,5 \\
10,1\end{array}$ & $\begin{array}{c}3,7 \\
7,4 \\
11,1\end{array}$ & 0,643 \\
\hline $\begin{array}{l}\text { Mielialaa tasaavat } \\
\text { lääkkeet }\end{array}$ & 1 & kaikki & 0,5 & 0,4 & 0,883 & 0 & 0,3 & 0,126 \\
\hline $\begin{array}{l}\text { Keskushermostoa } \\
\text { stimuloivat lääkeaineet }\end{array}$ & N06B & kaikki & 0,3 & 0,1 & 0,196 & 0 & 0 & \\
\hline $\begin{array}{l}\text { Psyykenlääkkeiden } \\
\text { yhdistelmävalmisteet }\end{array}$ & N06C & kaikki & 0,4 & 0,2 & 0,256 & 1,0 & 0,6 & 0,099 \\
\hline Dementialäk̈keet & N06D & kaikki & 0 & 0,04 & 0,648 & 2,8 & 5,6 & $<0,001$ \\
\hline $\begin{array}{l}\text { Jokin em. psyykenlääke } \\
\text { (pois lukien N06D) }\end{array}$ & & kaikki & 22,6 & 13,8 & $<0,001$ & 28,1 & 27,0 & 0,508 \\
\hline
\end{tabular}

${ }^{1}$ litium (N05AN01) ja/tai epilepsialääke (N03AF01, N03AG01 ja N03AX09 ostettuna erityiskorvauksen koodilla 112)

merkitsevästi useampi työikäinen omaishoitaja, jolla ansiotyö ei ollut pääasiallinen toimeentulo (29\%) kuin ansiotyötä tehnyt (17\%; $<<0,001)$.

Ikääntyneissä vertailtavien ryhmien välillä ei ollut merkitsevää eroa psyykenlääkettä kaikkiaan ostaneiden osuuksissa ( $28 \%$ vs. $27 \%$ ) (Taulukko 2). Ikääntyneet omaishoitajat ostivat yleisimmin unilääkettä $(18 \%)$ ja masennuslääkettä (10\%). Kuitenkin psykoosilääkettä osti harvempi ikääntynyt omaishoitaja (2\%) kuin vertailuväestöön kuuluva $(5 \% ; \mathrm{p}=0,004)$. Dementialääkettä ostivat harvemmat omaishoitajat kuin vertailuväestön tutkittavat (3\% vs. $6 \%$; $\mathrm{p}<0,001)$.
Omaishoitajilla psyykenlääkkeen ostamisen ja lääkehoidon erityskorvausoikeuksien yleisyyden välillä oli yhteys: omaishoitajissa, joilla oli vähintään yksi erityiskorvausoikeus, oli merkitsevästi enemmän psyykenlääkettä ostaneita $(30 \%)$ verrattuna omaishoitajiin, joilla ei ollut yhtään erityiskorvausoikeutta $(21 \%$; $<<0,001)$.

Omaishoitajien ostamien psyykenlääkkeiden vakioidut vetosuhteet (95\%:n lv) verrattuna väestöön olivat tilastollisesti merkitseviä seuraavissa ryhmissä: työikäisillä miehillä unilääkkeen ostolle 1,37 (1,07-1,76), työikäisillä naisilla masennuslääkkeen ostolle 1,17 (1,05-1,30) ja psykoosilääkkeen ostolle $0,76(0,61-0,95)$ sekä 


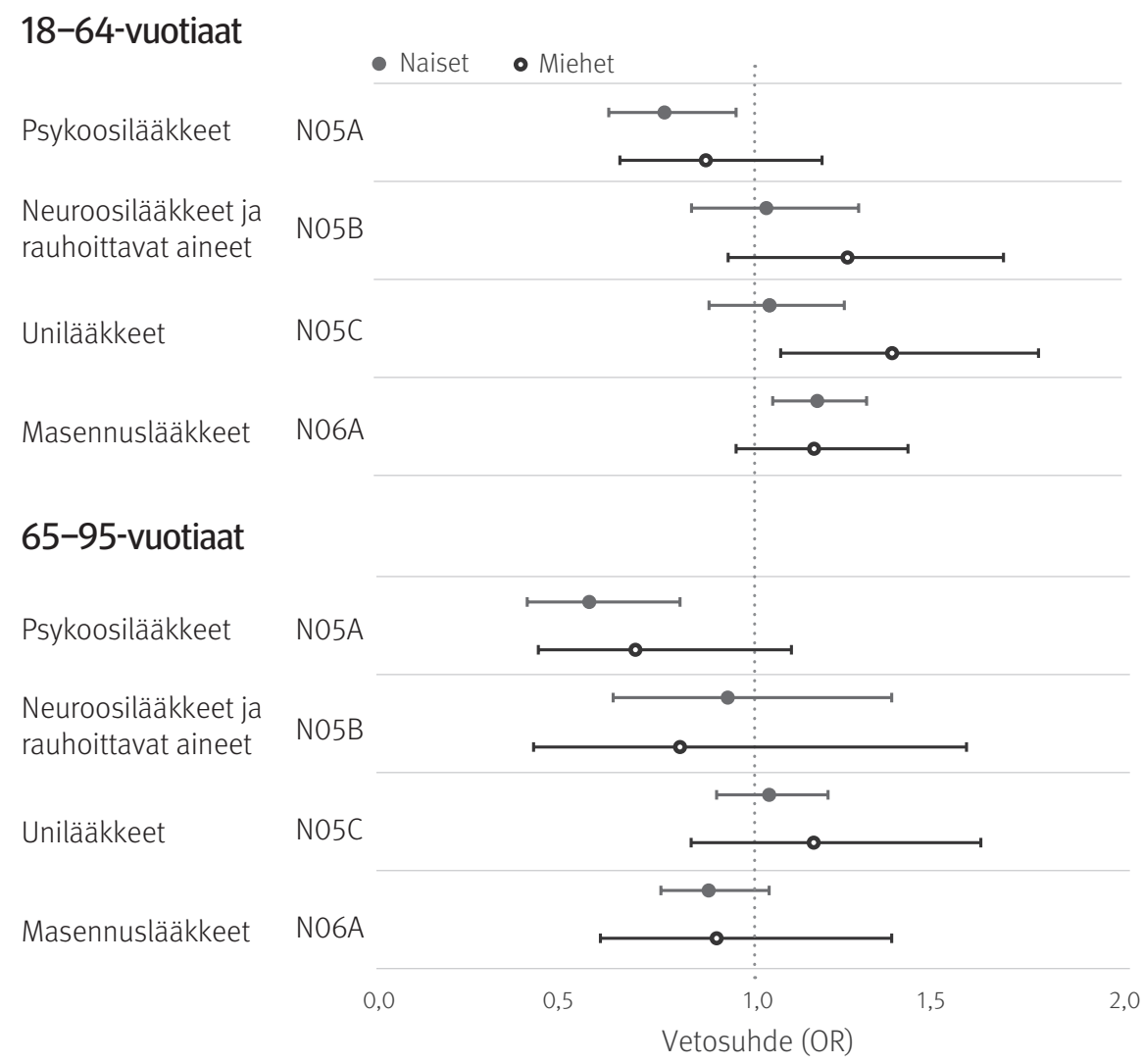

Kuvio. Vetosuhteet (odds ratio, OR) 95 \% luottamusväleineen (lv) yleisimmin käytettyjen psyykenlääkeryhmien lääkkeiden ostamiselle oululaisilla omaishoitajilla ja vertailuväestöllä vuonna 2013 (työikäiset vakioituna ikävuosin sekä työtilanteen ja erityiskorvausoikeuden tiedoilla; ikääntyneet vakioituna ikävuosin ja erityiskorvausoikeuden tiedolla).

ikääntyneillä naisilla psykoosilääkkeen ostolle 0,56 (0,39-0,80; kuvio).

\section{OMAISHOIDETTAVAT}

Omaishoidettavia oli aineistossa 1942 henkilöä eli $1,0 \%$ Oulun väestöstä vuonna 2013. Heidän keski-ikänsä oli 60 vuotta ja ikääntyneet olivat selvänä enemmistönä, $60 \%$ (taulukko 3). Miespuolisia oli $53 \%$ kaikista hoidettavista ja $66 \%$ alle 16-vuotiaista.

Oletuksena oli, että omaishoidettavan heikko terveydentila ja raskashoitoisuus olisivat yhteydessä siihen, kuinka psyykkisesti kuormittunut olisi hänen omaishoitajansa. Lähes kaikki hoidettavat saivat jotain Kelan vammaisetuutta, ja niiden yleisin taso oli korotettu tuki (45 \%:1la hoidettavista) (taulukko 3). Vammaisetuuksien sairauskirjot erosivat merkitsevästi kolmen ikäryhmän välillä, kuten erosivat ikäryhmittäin myös psyykenlääkettä ostaneiden osuudet. Lapsilla ja työikäisillä vammaisetuuden yleisin peruste oli mielenterveyden ja käyttäytymisen häiriöiden tautiryhmä (F-ryhmä). Näillä lapsilla lähes yhtä yleisiä olivat psyykkisen kehityksen häiriöt ja älyllinen kehitysvammaisuus (yhteensä 87 \% F-ryhmän päädiagnooseista) ja työikäisillä yleisin päädiagnoosi oli älyllinen kehitysvammaisuus (58\% F-ryhmästä). Ikääntyneillä yleisin tautiryhmä oli hermoston sairaudet, jossa kolmella neljästä etuuden päädiagnoosina oli Alzheimerin tauti. Omaishoidettavista $9 \%$ kuoli vuoden 2013 kuluessa (taulukko 3).

Vuoden aikana lähes jokaisella omaishoidettavalla oli vähintään yksi sairausvakuutuksen korvaama lääkeosto (taulukko 3). Neljällä viidestä omaishoidettavasta oli oikeus ainakin yhden pitkäaikaissairauden lääkityksen erityiskorvaukseen. Psyykenlääkkeen käyttö yleistyi hoidetta- 
Taulukko 3. Oululaisten vuonna 2013 omaishoidettavina olleiden henkilöiden taustatietoja ikäryhmittäin.

$\begin{array}{cccc}1-15- & 16-64- & 65-103- & \\ \text { vuotiaat } & \text { vuotiaat } & \text { vuotiaat } & \text { p-arvo } \\ \mathrm{N}=322 & \mathrm{~N}=453 & \mathrm{~N}=1167 & \end{array}$

Osuus omaishoidettavista, \%

Väestöosuus, \%

Naisia, \%

Keski-ikä, vuosia (keskihajonta)

Kuolleita vuoden 2013 aikana, \%

Kelan vammaisetuuden luokka, \%

- ylin

- korotettu

- perus

- ei vammaisetuutta

Kelan vammaisetuuden päädiagnoosin tautiryhmä, \% ICD-10

- mielenterveyden ja käyttäytymisen häiriöt

- hermoston sairaudet

- verenkiertoelinten sairaudet

- tuki- ja liikuntaelinten sekä sidekudoksen sairaudet

- synnynnäiset epämuodostumat ja kromosomipoikkeavuudet

- muut pääryhmät yhteensä

- ei vammaisetuutta

Lääkityksen erityiskorvausoikeus, \%

- ei erityiskorvausoikeuksia

- yhteen pitkäaikaiseen sairauteen

- useampaan kuin yhteen pitkäaikaiseen sairauteen

Vähintään yksi korvattu lääkeosto vuoden aikana, \%

Vähintään yksi korvattu psyykenlääkkeen² osto vuoden aikana, \%

- psykoosilääkkeet

- neuroosilääkkeet ja rauhoittavat aineet

- unilääkkeet

- masennuslääkkeet

- keskushermostoa stimuloivat lääkeaineet

- dementialääkkeet

\section{$\mathrm{F}$}

G

I

$\mathrm{M}$

Q

20,5
16,5

- $\quad 2,2$

100,0

50,0

29,5

20,5

100,0

75,8

ATC

N05A

N05B

N05C

N06A

N06B

N06D

49, 1

9,9

0,9

0,9

20,5

28,6

12,1

0,6
16,6

0,8

33,8

$9,0(3,8)$

0,9

38,5

54,0

2,2

100,0

23,3
0,4
48,3
$43,0(17,0)$
4,9

60,1

4,4

0,5

, $(7,7)$

$13,4<0,001$

$$
<0,001
$$

29,4

$26,7^{1}$

$45,9^{1}$

41,3

$19,4^{1}$

24,6

8,0

4,7

100,0

100,0

$<0,001$

26,5

22,7

9,1

6,2

6,8

34,2

24,9

8,7

7,7

0,2

19,8

20,5

$8,0 \quad 4,7$

100,0

100,0

$<0,001$

6,0

19,3

74,7

100,0

$96,7<0,001$

90,7

47,2

$49,4<0,001$

19,2

$15,7 \quad 0,002$

20,3

11,0

$<0,001$

13,9

20,4

$<0,001$

26,3

27,2

$<0,001$

0,4

0

$<0,001$

2,9

36,2

$<0,001$

\footnotetext{
${ }^{1} 16$ vuotta täyttäneen vammaistuki tai eläkettä saavan hoitotuki
}

2 ATC-koodit N05A, N05B, N05C, N06A, N06B, N06C 
vien iän myötä: ostaneita oli 29 \% lapsista, 47 \% työikäisistä ja $49 \%$ ikääntyneistä hoidettavista ( $<<0,001)$. Lapsista $9 \%$ :lla oli vähintään yksi keskushermosta stimuloivien lääkeaineiden osto. Työikäisistä hoidettavista $19 \%$ :lla oli psykoosilääkkeen osto ja $20 \%$ :lla neuroosilääkkeen tai rauhoittavan aineen osto. Ikääntyneistä hoidettavista $20 \%$ :lla oli unilääkkeen ja $27 \%$ :lla masennuslääkkeen osto. Lähes kahdella viidestä ikääntyneestä hoidettavasta oli dementialääkkeen osto.

\section{POHDINTA}

Suomalaisten omaishoitajien psyykenlääkkeiden käytön yleisyydestä ei löytynyt julkaistua tietoa. Rekisteritutkimuksemme mukaan jotain sairausvakuutuksen korvaamaa psyykenlääkettä osti yksi neljästä omaishoitajasta, joille maksettiin omaishoidon tuen hoitopalkkiota vuonna 2013. Työikäiset omaishoitajat ostivat yleisimmin masennuslääkettä ja ikääntyneet unilääkettä.

Päähavaintomme, että psyykenlääkettä käytti hieman suurempi osa omaishoitajista kuin vertailuväestöstä, on samansuuntainen harvojen ulkomaisten tutkimusten tulosten kanssa $(17,18)$. Aikaisemmat tutkimukset ovat kohdistuneet ikääntyneisiin omaishoitajiin tai dementiapotilaiden omaishoitajiin, useimmiten puolisoihin. Omassa aineistossamme omaishoitajien iän yhteys psyykenlääkkeiden käyttöön ilmeni siten, että käyttö oli väestöä yleisempää työikäisillä omaishoitajilla ( $24 \%$ vs. $14 \%$ ), muttei ikääntyneillä (25\% vs. $27 \%$ ). Psyykkisesti oireilleiden omaishoitajien ja heidän verrokkiensa todellinen määrä oli ilmeisesti suurempi kuin mitä lääkeostoista voi päätellä, sillä kaikki oireiset eivät käytä psyykenlääkitystä. Tämä harha vaikutti todennäköisesti likimain samassa määrin vertailtaviin ryhmiin.

Yleisemmin käytettyjen psyykenlääkeryhmien perusteellisemmassa tarkastelussa ja myös hoitajan sukupuoli huomioiden tuloksena oli, että työikäisten miesten unilääkkeen ostamisen vetosuhde väestöön verrattuna oli 1,4 ja työikäisten naisten vetosuhde masennuslääkkeen ostamiselle 1,2, kun vakioitiin omaishoitajien ja verrokkien erot iässä, ansiotyön tekemisessä ja lääkkeiden erityiskorvausoikeuksissa. Omaishoitajien ikäryhmiä koskeva havaintomme on samansuuntainen kuin aiemmissa omaishoitajien psyykkistä oireilua käsittelevissä tutkimuksissa: omaishoitajuuden ja psyykkisten oireiden yleisyyden välillä on raportoitu merkitseviä yhteyksiä työikäisillä muttei ikääntyneillä hoitajilla $(20,25)$. Työikäisiä koskevien tulostemme tulkinta on, että unettomuus haittaa erityisesti miespuolisia omaishoitajia ja masennus naispuolisia. Toisaalta voidaan pohtia, johtuuko ero esimerkiksi miesten ja naisten välisistä eroista hoitoon hakeutumisessa tai siitä, että samankaltaisiakin psyykkisiä ongelmia diagnosoidaan ja/tai lääkitään eri tavoin sen mukaan, onko potilas mies vai nainen.

Psykoosilääkkeen käyttö oli harvinaisempaa naispuolisilla omaishoitajilla kuin heidän vertailuväestössään, ja toisaalta dementialääkkeen käyttö oli kaksi kertaa yleisempää vertailuväestössä kuin ikääntyneillä omaishoitajilla. Nämä havainnot ovat loogisia, koska voidaan arvioida, että psykoosilääkitystä tai muistilääkitystä tarvitsevalla ei yleensä ole riittävää toimintakykyä toimiakseen omaishoitajana.

Työiässä omaishoitajana toimiminen saattaa johtaa osa-aikaiseen työskentelyyn tai kokonaan pois ansiotyöstä. Oulussa ansiotyö oli pääasiallinen tulolähde harvemmalla omaishoitajalla (57\%) kuin vertailuväestön työikäisellä (73\%). Mahdollinen tulkinta voisi olla myös, että osa ryhtyi omaishoitajaksi vasta tilanteessa, jossa työllistyminen muualle oli pitkään vaikeaa aikaisemmin ilmenneen oman sairauden tai muun syyn takia. Tällöin omaishoidon yhtenä motiivina voi olla se, että omaishoitajuus takaa hoitajalle edes pienen säännöllisen ansiotulon. Tähän saattaa viitata aiempi havainto työikäisten omaishoitajien tuloista: naisista kolme ja miehistä seitsemän prosenttia ei saanut muita tuloja hoitopalkkion ohella ja lisäksi miesten mediaanitulo pieneni jo kolme vuotta ennen omaishoidon tukea (26). Myös amerikkalaisia ikääntyneitä omaishoidettavia koskevassa tutkimuksessa havaittiin, että heidän omaishoitajistaan vähintään yksi viidestä oli vähentänyt ansiotyötään tai lopettanut sen kokonaan (27).

Useimmat omaishoitajuuden yhteyttä hoitajan psyykkiseen toimintakykyyn tai psyykenlääkkeiden käyttöön selvittäneet tutkimukset, kuten myös oma tutkimuksemme, on toteutettu poikkileikkausasetelmalla, mikä ei mahdollista ilmiön syy-seuraussuhteen luotettavaa päättelyä. 
Siksi työikäisten omaishoitajien vertailuväestöä yleisempää psyykenlääkkeiden käyttöä ei voi tulkita siten, että yksistään omaishoitajuus selittäisi ryhmien väliset erot. On esimerkiksi mahdollista, että työikäisten omaishoitajien psyykkinen oireilu oli ollut muuta väestöä jonkin verran yleisempää pitkään ja ilmennyt jo ennen omaishoitajuutta. Tähän Oulun aineistossa voi viitata se, että työikäisillä omaishoitajilla oli vertailuväestöä useammin joko erityiskorvausoikeus pitkäaikaisen ja vaikean sairauden lääkitykseen tai Kelan maksama vammaisetuus. Toinen tulkinta voisi olla, että hoidettaviensa ohessa omaishoitajat itsekin saattoivat osata hakeutua keskimääräistä sujuvammin tarpeellisten hoitopalvelujen piiriin, mihin sopisi heidän vertailuväestöä yleisempi kaikkien lääkkeiden käyttönsä. Tutkimuksemme lähtöolettamuksen - omaishoitajien psyykenlääkityksen yleisyydestä kyettäisiin päättelemään jotakin heidän psyykkisestä terveydentilastaan tai jaksamisestaan väestöön verrattuna - lisäheikkous on se, että psyykenlääkkeitä määrätään myös muun kuin psyykkisen sairauden hoitoon. Jotkut tutkittavat ovat saattaneet käyttää psyykenlääkettä ensisijaisesti esimerkiksi pitkäaikaisen kivun lievitykseen tai jonkin neurologisen sairauden hoitoon. Jatkotutkimusten tärkeänä aiheena olisikin selvittää omaishoitajien lääkekäytön lisäksi myös heidän psykiatristen ja muiden terveyspalveluiden käyttöään muuhun väestöön verrattuna.

Tutkimuksemme keskeinen vahvuus on laaja rekisteriaineisto, joka sisältää luotettavaa, kattavaa ja monipuolista tietoa yhden suuren kaupungin kaikista omaishoitajan palkkiota saaneista omaishoitajista sekä omaishoidettavista. Aineistossa ei siten ole kyselytutkimuksille ominaista puuttuvuutta eikä itseraportoinnista aiheutuvaa harhaa.

Vaikka oululaisten omaishoitajien osuus $(1,2 \%)$ kaupungin aikuisväestöstä oli vuonna 2013 jonkin verran suurempi kuin vastaavasti koko maan omaishoitajien silloinen keskimääräinen väestöosuus, edustivat he vain noin viittä prosenttia maan kaikista omaishoitajista. Pienen kohdejoukon takia tämän tutkimuksen tuloksia tulee yleistää varauksella koskemaan maan kaikkia omaishoitajia. Jatkotutkimuksia kaivataan omaishoitajien psyykenlääkkeiden ja mahdollisesti muidenkin lääkkeiden käytöstä valtakun- nallisella aineistolla. Tutkimuksemme heikkoutena on myös, ettei käytettävissä ollut tietoa kunkin omaishoitajan toteuttaman hoidon sitovuudesta (ajallisesta kestosta) ja vaativuudesta, jotka myös mahdollisesti olisivat olleet yhteydessä hoitajan psyykkiseen kuormittuneisuuteen ja siten myös psyykenlääkkeen käytön yleisyyteen $(19,20)$. Tutkitut psyykenlääkeryhmät olivat reseptilääkkeitä paria itsehoitovalmistetta lukuun ottamatta. Psyykenlääkkeiden osalta Kelan reseptirekisterin kattavuutta 2000-luvulla voidaan pitää hyvänä; N05-valmisteiden osalta keskimäärin 72-90\% ja N06 osalta $90 \%(28,29)$. Sairausvakuutuksen korvauksen piiristä puuttui joidenkin valmisteiden tiettyjä pakkauskokoja ja äskettäin markkinoille tulleita uusia lääkkeitä. Lisäksi tutkimusaineistosta todennäköisesti puuttui pieni osa reseptiostoista, jotka lunastettiin ilman sairausvakuutuskorttia. Koska ostotietojen vähäinen kato todennäköisesti kohdistui samassa määrin omaishoitajiin ja heidän vertailuväestöönsä, aiheutunut harha tuskin vaikutti olennaisesti tulostemme tulkintaan.

Enemmistö aineiston omaishoidettavista sai todennäköisesti vaativaa hoitoa tai hoivaa. Tämä arvioitiin sen perusteella, että lähes kaikki hoidettavat saivat Kelan vammaisetuutta ja kolme neljästä sai vähimmäismäärää korkeampaa tukea, suureen tai päivittäiseen avuntarpeeseensa. Omaishoidettavilla vammaisetuuksien yleisimmät diagnoosit olivat kehitysvammaisuus ja Alzheimerin tauti. Lähes jokaisella hoidettavalla oli lääkeostoja ja vähintään joka toisella oli jonkin tietyn lääkityksen erityiskorvausoikeus. Psyykenlääkkeiden käyttö oli yleistä: ikääntyneistä omaishoidettavista joka toisella oli jokin psyykenlääkitys ja kaksi viidestä käytti dementialääkettä. Siten monia heidän hoitajiaan mahdollisesti kuormittivat jo yksistään hoidettavan monilukuisen lääkehoidon päivittäiset annostelut. Omaishoidettavien raskashoitoisuuteen viittaa myös se, että heistä lähes yksi kymmenestä menehtyi vuoden 2013 aikana.

Omaishoidon ja Kelan vammaisetuuksien päällekkäisyys on tunnettu asia; varsinkin omaishoidon tuella hoidettavat lapset ovat tavanmukaisesti saaneet myös alle 16-vuotiaan vammaistukea (30). Sen sijaan uusi havainto on se, että myös osa omaishoitajista sai vammaisetuuksia: niitä Kela maksoi Oulussa viidelle prosentille 
työikäisistä ja kymmenelle prosentille ikääntyneistä omaishoitajista. Tämä on mielenkiintoista, sillä aikuiselle vammaisetuuden myöntämisen perusehto on, että sairauden tulee heikentää henkilön toimintakykyä vähintään vuoden ajan (23).

Omaishoitajuuteen voi tapahtua valikoitumista eri syistä. Sittemmin omaishoitotehtävän myötä joidenkin hoitajien psyykkinen terveydentila heikkenee, toisilla ansiotyö vähenee tai estyy kokonaan, ja osalla saattaa tapahtua niitä kumpaakin (31). Kaikkiaan omaishoitajat vaikuttavat varsin heterogeeniseltä ryhmältä. Joka tapauksessa omaishoito on vaativa työtehtävä ja voi kestää vuosien ajan, jolloin useimpien hoitajien jaksamista toimessaan on tärkeää tukea monin tavoin. Psyykkisen terveyden säilyminen on ensiarvoisen tärkeää henkilölle, joka huolehtii toimintakyvyltään heikentyneen, sairaan ja/tai vammaisen ihmisen tarpeista ja hyvinvoinnista. Jos omaishoitajalle kuitenkin määrätään psyykenlääkettä, on huomioon otettava myös lääkkeen mahdolliset haittavaikutukset, jotka voivat vaikeuttaa omaishoitajana toimimista. Jatkossa sosiaali- ja terveydenhuollon toimijoiden tulee kiinnittää riittävästi huomiota omaishoidossa olevan lisäksi myös hänen omaishoitajanaan toimivan psyykkiseen terveydentilaan ja jaksamiseen.

\section{KIITOKSET:}

Kirjoittajat kiittävät tutkija Pekka Heinoa, joka osallistui omaishoitajien, vertailuväestön ja omaishoidettavien ryhmien muodostamiseen.

\section{RAHOITTAJAT:}

Tutkimus tehtiin Kelan työsuhteissa.

\section{KIRJOITTAJIEN KONTRIBUUTIOT:}

Virta, Tillman ja Blomgren laativat tutkimussuunnitelman ja -kysymykset. Virta analysoi tulokset ja kirjoitti käsikirjoituksen ensimmäisen version. Tillman ja Blomgren osallistuivat käsikirjoituksen kirjoittamiseen ja kriittiseen kommentointiin. Kaikki kirjoittajat ovat hyväksyneet lopullisen käsikirjoituksen.

\section{Virta, L., Tillman, P., Blomgren, J. Use of psychoactive medications among informal caregivers: a register-based study on persons living in Oulu, Finland, 2013. Sosiaalilääketieteellinen aikakauslehti - Journal of Social Medicine 20 I9: 56: 204-2I5.}

Use of psychoactive medications can be considered an indicator of informal caregivers' mental health and psychological distress. No comparable research has previously been published in Finland. We investigated differences between the share of informal caregivers and others of the same age who purchased psychoactive medications during the calendar year. We also looked at the health status of informal care recipients and the proportion who purchased psychoactive medications. The study was based on registry data on persons living in Oulu in 2013. The data were analysed with descriptive statistical methods and logistic regression analysis.

The mean age of informal caregivers ( $\mathrm{N}=1905)$ was 59 years. Sixty-two percent were women. One in four caregivers on average had purchased a psychoactive medication covered by the $\mathrm{Na}$ tional Health Insurance scheme. Working-age informal caregivers (18 to 64 years) were most likely to have purchased antidepressive drugs $(16 \%)$, while the most common category among elderly caregivers (65 to 95 years) was sleep medicine $(18 \%)$. The share of persons who purchased psychoactive medications was higher among working-age informal caregivers than in the reference population ( $23 \%$ vs. $14 \%)$; no significant differences were observed among elderly caregivers. Some gender differences were discovered when purchases of psychoactive medications in the four most common drug categories were analysed more closely: among male working-age caregivers, the odds ratio of purchasing sleep medicines was 1.4 compared with the reference population, while the odds ratio of antidepressive medication purchases by female caregivers was 1.2. The use of antipsychotic drugs was lower among female caregivers than in the reference population: the odds ratios for working-age women and elderly women were 0.8 and 0.6 , respectively. The mean age of informal care recipients was 60 years, and 13 percent of the elderly recipients died in 2013. Every other informal care recipient had purchased psychoactive medications. 
Because informal care relationships typically last many years, it is important that those working or interacting with informal caregivers should pay attention to their psychological well-being. Supportive services and arrangements, including the psychological support of informal caregivers, should be developed further.

\section{LÄHTEET}

(1) Kansallinen omaishoidon kehittämisohjelma. Työryhmän loppuraportti. Helsinki: Sosiaali- ja terveysministeriö, Sosiaali- ja terveysministeriön raportteja ja muistioita 2,2014.

(2) Ratkaisujen Suomi. Pääministeri Juha Sipilän hallituksen strateginen ohjelma. Luettu 25.10.2018. https://valtioneuvosto.fi/sipilanhallitus/hallitusohjelma

(3) Laatusuositus hyvän ikääntymisen turvaamiseksi ja palvelujen parantamiseksi 2017-2019. Helsinki: Sosiaali- ja terveysministeriö, Sosiaali- ja terveysministeriön julkaisuja 6,2017.

(4) Laki omaishoidon tuesta 937/2005. www. finlex:fi/fi/laki/ajantasa/2005/20050937

(5) THL. Tilasto- ja indikaattoripankki Sotkanet. Luettu 25.10.2018. https://sotkanet.fi/sotkanet/ fi/in

(6) Tillman P, Kalliomaa-Puha L, Mattila Y, ym. Kyselytutkimus vuonna 2012 omaishoitajana olleille -kyselyn toteutus ja omaishoitajien, omaishoidettavien ja omaishoitotilanteen perustiedot. Julkaisussa P Tillman, L KalliomaaPuha, H Mikkola (toim.) 2014. Rakas mutta raskas työ. Kelan omaishoitohankkeen ensimmäisiä tuloksia. Kelan tutkimusosasto, Työpapereita 69; 2014, 56-68.

(7) Mäkelä M, Vilkko A, Blomgren J, ym. Avun antaminen. Teoksessa Koskinen S, Lundqvist A, Ristiluoma N (toim.) Terveys, toimintakyky ja hyvinvointi Suomessa 2011. THL, raportti 68/2012. Helsinki: Terveyden ja hyvinvoinnin laitos; 2012, 199-201.

(8) Andrén S, Elmståhl S. Family caregivers' subjective experiences of satisfaction in dementia care: aspects of burden, subjective health and sense of coherence. Scand J Caring Sci $2005 ; 19(2): 157-168$.

doi: 10.1111/j.1471-6712.2005.00328.x

(9) Etters L, Goodall D, Harrison BE. Caregiver burden among dementia patient caregivers: a review of the literature. J Am Acad Nurse Pract 2008;20(8):423-428. doi: 10.1111/j.1745-7599.2008.00342.x

(10) Vlachantoni A, Evandrou M, Falkingham J, ym. Informal care, health and mortality. Maturitas. 2013;74(2):114-118.

doi: 10.1016/j.maturitas.2012.10.013
Keywords: depression, informal care, outpatient care, sleep medicines

Saapunut 02.11 .2018

Hyväksytty 25.03.2019
(11) Berglund E, Lytsy P, Westerling R. Health and wellbeing in informal caregivers and noncaregivers: a comparative cross-sectional study of the Swedish general population. Health Qual Life Outcomes 2015;13:109. doi: 10.1186/s12955-015-0309-2

(12) Pinquart M, Sörensen S. Differences between caregivers and noncaregivers in psychological health and physical health: A meta-analysis. Psychol Aging 2003;18:250-267. doi: 10.1037/0882-7974.18.2.250

(13) Cuijpers P . Depressive disorders in caregivers of dementia patients: a systematic review. Aging Ment Health. 2005;9(4):325-330. doi: 10.1080/13607860500090078

(14) Zanetti O, Frisoni GB , Bianchetti A, ym Depressive symptoms of Alzheimer caregivers are mainly due to personal rather than patient factors. Int J Geriatr Psychiatry 1998;13(6):358-367. doi: 10.1002/1099-1166(199806)

(15) Sleath B, Thorpe J, Landerman LR, ym. African-American and white caregivers of older adults with dementia: differences in depressive symptomatology and psychotropic drug use. J Am Geriatr Soc 2005;53(3):397-404. doi: 10.1111/j.1532-5415.2005.53155.x

(16) Camargos EF, Souza AB, Nascimento AS, ym. Use of psychotropic medications by caregivers of elderly patients with dementia: is this a sign of caregiver burden? Arq Neuropsiquiatr 2012;70(3):169-174. doi: 10.1590/S0004-282X2012000300003

(17) Clipp EC, George LK. Psychotropic drug use among caregivers of patients with dementia. J Am Geriatr Soc 1990;38(3):227-235. doi: 10.1111/j.1532-5415.1990.tb03496.x

(18) Mort JR, Gaspar PM, Juffer DI, ym. Comparison of psychotropic agent use among rural elderly caregivers and noncaregivers. Ann Pharmacother 1996;30(6):583-585. doi: 10.1177/106002809603000602

(19) Van Houtven C, Wilson MR, Clipp EC. Informal care intensity and caregiver drug utilization. Review of economics of the household 2005;3:415-433. doi: $10.1007 / \mathrm{s} 11150-005-4942-0$ 
(20) Doebler S, Ryan A, Shortall S, ym. Informal care-giving and mental ill-health. Differential relationships by workload, gender, age and arearemoteness in a UK region. Health Soc Care Community 2017;25(3):987-999.

doi: 10.1111/hsc.12395

(21) Miettinen J, Aaltonen K, Martikainen JE. Lääkemääräysten alkuperän määrittäminen terveydenhuollon käyntitietojen avulla.

Menetelmäraportti Oulu-hankkeessa käytetystä algoritmista. Työpapereita 108. Helsinki: Kela; 2016.

(22) WHO Collaborating Centre for Drug Statistics Methodology, Norvegian institute of public health. Oslo: International language for drug utilization research. https://www.whocc.no/ atc_ddd_index/

(23) Laki vammaisetuuksista 570/2007. www. finlex:fi/fi/laki/ajantasa/2007/20070570

(24) Allison PD. Logistic regression using SAS: theory and application. Second edition. Cary, NC: SAS Institute Inc; 2012, 160-187.

(25) Koyanagi A, DeVylder JE, Stubbs B, ym. Depression, sleep problems, and perceived stress among informal caregivers in 58 low-, middle-, and high-income countries: A cross-sectional analysis of community-based surveys. J Psychiatr Res 2018;96:115-123. doi: 10.1016/j.jpsychires.2017.10.001

(26) Mikkola H, Komu M, Räsänen T, ym. Omaishoitajien tulorakenne ja - kehitys - onko tuella merkitystä? Esitys Omaishoito tänään ja huomenna -seminaarissa, 10.3.2016 Kela, Helsinki. Luettu 19.7.2018. https://www. slideshare.net/kelantutkimus/mikkola-et-alomaishoitajien-tulorakenne-ja-tulokehitys

(27) Covinsky KE , Eng C , Lui LY . Reduced employment in caregivers of frail elders: impact of ethnicity, patient clinical characteristics, and caregiver characteristics. J Gerontol A Biol Sci Med Sci 2001;56(11):M707-713. doi: 10.1093/gerona/56.11.m707
(28) Vuorenmaa M. Lääkemääräyskäytännön tutkiminen ja Kelan reseptitiedoston kattavuus. Kuopion yliopisto, Sosiaalifarmasian laitos: pro gradu -tutkielma, proviisorin koulutusohjelma; helmikuu 2008, 74-75.

(29) Kurko T, Saastamoinen LK, TuulioHenriksson A, ym. Trends in the long-term use of benzodiazepine anxiolytics and hypnotics: A national register study for 2006 to 2014. Pharmacoepidemiol Drug Saf. 2018 Jun;27(6):674-682. doi: $10.1002 /$ pds.4551.

(30) Kalliomaa-Puha L, Tillman P. Äiti on aina äiti; Lasten omaishoitajien arjen haasteet. Julkaisussa Haataja A, Airio I, Saarikallio-Torp M, ym. (toim.) Laulu 573566 perheestä. Lapsiperheet ja perhepolitiikka 2000-luvulla. Helsinki: Kela, Teemakirja 15; 2016, 346-347.

(31) Wilson MR, Van Houtven CH, Stearns S C, ym. Depression and missed work among informal caregivers of older individuals with dementia. J Fam Econ Iss 2007; 28(4): 684-698. doi: 10.1007/s10834-007-9081-8.

\section{LAURI VIRTA}

LKT, dosentti, tutkijalääkäri

Kelan tutkimus

PäIVI TIllmaN

VTL, tutkija

Kelan tutkimus

JENNI BLOMGREN

VTT, dosentti, tutkimuspäällikkö

Kelan tutkimus 